\title{
Effect of Brown Rust on Yield of Sugarcane in Louisiana
}

\author{
J. W. Hoy and C. A. Hollier, Department of Plant Pathology and Crop Physiology, Louisiana State University Agri- \\ cultural Center, Baton Rouge 70803
}

\begin{abstract}
Hoy, J. W., and Hollier, C. A. 2009. Effect of brown rust on yield of sugarcane in Louisiana. Plant Dis. 93:1171-1174.

Brown rust, caused by Puccinia melanocephala, can cause severe epidemics in susceptible sugarcane cultivars during spring and early summer in Louisiana. The effect of the disease on yield was evaluated in field experiments conducted during three growing seasons. A mixture of three fungicides-azoxystrobin, propiconazole, and tebuconazole-applied biweekly during the spring epidemic period kept brown rust severity low $(<5 \%)$, and plants protected by fungicide applications throughout the epidemic provided an estimate of attainable yield for comparison with plants naturally infected with rust. A combined analysis over three seasons estimated brown rust caused reductions of 16 and $14 \%$ in cane tonnage and total amount of sucrose produced, respectively, in cv. LCP 85-384. The greatest reduction in total sucrose yield of $22 \%$ resulted from the epidemic of longest duration, and stalk weight was negatively correlated with rust severity. Comparisons of the yields obtained from plots in which brown rust was controlled early versus late in the epidemic suggested that the impact of the disease is greatest from the middle to late epidemic period when stem elongation has begun.
\end{abstract}

Brown rust, caused by Puccinia melanocephala Syd. \& P. Syd., is an important disease of sugarcane (interspecific hybrids of Saccharum L. spp.) in many production areas around the world (12). The disease is managed by breeding and selecting for host plant resistance. As with many rust diseases, the adaptability of the pathogen affects resistance durability and makes brown rust a continual threat and an ongoing challenge for breeding programs. Conclusive evidence for the existence of different races is limited for brown rust. One study in Florida documented differential brown rust reactions among a set of six sugarcane cultivars (14). Shifts in cultivar reactions from resistance to susceptibility have been observed in many areas $(1,3,9,10,15)$.

Changing cultivars cannot be accomplished quickly in sugarcane because of the multiyear crop cycle and the need for an adequate supply of healthy planting material for vegetative propagation. This difficulty in rapidly changing cultivars results in a situation in which periodic significant economic losses due to brown rust are possible.

Brown rust was first observed in Louisiana during the late 1970s. Sugarcane is grown in Louisiana at the northern limit of its cultivation range (latitude $30^{\circ} \mathrm{N}$ ), and

Corresponding author: J. W. Hoy

E-mail: jhoy@agcenter.lsu.edu

Accepted for publication 12 July 2009.

doi:10.1094/PDIS-93-11-1171

(C) 2009 The American Phytopathological Society the occurrence of winter freezes can delay the start and reduce the severity of annual brown rust epidemics. However, in some seasons, severe epidemics occur in susceptible cultivars, and field observations over time have indicated shifts in the reaction of some cultivars to brown rust from resistant to susceptible.

Sugarcane is an indeterminate growth grass, and new leaves emerge continuously at the shoot apex. Planting by vegetative propagation takes place in late summer in Louisiana. Shoots emerge and some tillering takes place before winter. Intermittent growth may occur during warm periods but winter frosts and freezes periodically damage or kill aboveground leaf tissue. Plants resume growth during spring. Tillering and some shoot growth occur during this period. Shoot elongation then rapidly increases in summer and stalks develop. Sucrose accumulation takes place as plants mature during fall. Severe brown rust epidemics typically occur during the tillering and early stalk development stages of crop development (12).

Negative impacts of brown rust on sugarcane yield have been reported $(2,6,11,13,16,17)$. Field losses associated with brown rust greater than $50 \%$ have been documented, depending on cultivar susceptibility and growing conditions. However, the effect of the disease on sugarcane yield components during Louisiana's short growing season has not been evaluated previously. One effect of the winter freezes that occur in Louisiana is that crop growth is synchronized, and severe brown rust epidemic conditions occur during the late spring months, extending into early summer. Brown rust epidemics are curtailed by high summer temperatures and increased resistance in older plants $(1,9)$. The objectives of this study were to determine the effect of brown rust on sugarcane yield components during the Louisiana growing season and evaluate the impact of disease on yield during different periods of the epidemic.

\section{MATERIALS AND METHODS}

Field experiments were conducted in commercial sugarcane fields in three successive years, 2004 to 2006. All three experiments were conducted in the plant cane (first-year) crop of cv. LCP 85-384 (8). A mixture of three fungicides (azoxystrobin, propiconazole, and tebuconazole) was used to control brown rust development during the spring epidemic period. A mixture of fungicides with different modes of action was used because fungicide efficacy for brown rust control had not been thoroughly evaluated. Fungicide applications were initiated when rust symptoms were first detected and were made thereafter at approximately 2-week intervals. In order to gain further information about the impact of brown rust, treatments were initiated and stopped at different times during the epidemic period. No fungicides were applied after mid-June because rust infection and lesion development on leaves emerging after this time was negligible.

Azoxystrobin (Quadris, 22.9\% active ingredient [a.i.]; Syngenta Crop Protection, Inc., Greensboro, NC) was applied at a rate of a.i. at $104 \mathrm{ml} / \mathrm{ha}$. Propiconazole (Tilt, $41.8 \%$ a.i.; Syngenta Crop Protection) was applied at a rate of a.i. at $74 \mathrm{ml} / \mathrm{ha}$. Tebuconazole (Folicur 3.6 F, 38.7\% a.i.; Bayer CropScience, Research Triangle Park, NC) was applied at a rate of a.i. at $170 \mathrm{ml} / \mathrm{ha}$. The spray volume of water was $140 \mathrm{li}$ ters/ha. The fungicide mixture was applied to plant foliage with a $\mathrm{CO}_{2}$ backpack sprayer at a pressure of $172 \mathrm{kPa}$ with three nozzles per row containing 8002VS flat fan tips.

The fungicide mixture was applied on different combinations of dates to create multiple treatments providing crop protection during different periods of the epidemic each season. During the 2004 epidemic, fungicide treatments were initiated on 4 April. Six total treatments consisted of fungicides applied on 4 April and 20 April (early); 4 April, 20 April, 5 May, and 19 May (early-mid); 4 April, 20 April, 5 May, 19 May, 1 June, and 19 June (full); 5 May, 19 May, 1 June, and 19 June (midlate); 1 June and 19 June (late); and a 
nontreated control. During 2005, the epidemic began later, with the first fungicide application on 3 May. Four total treatments consisted of fungicides applied on 3 May and 17 May (early); 3 May, 17 May, 2 June, and 15 June (full); 2 June and 15 June (late); and a nontreated control. The epidemic during 2006 also began later, and the first fungicide application date was 8 May. Four total treatments consisted of fungicide applications on 8 May and 18 May (early); 8 May, 18 May, 1 June, and 15 June (full); 1 June and 15 June (late); and a nontreated control.

The experimental design for each study field was a randomized complete block with four replications. Individual plots for each treatment consisted of two rows, 18.3 $\mathrm{m}$ in length, with a $1.8-\mathrm{m}$ row spacing. There were $1.5-\mathrm{m}$ nontreated sections of row interspersed along rows between plots, with a lateral separation of two nontreated rows between sets of treated rows.

Brown rust severity in the different treatments was determined by performing image analysis (ASSESS 1.0; American Phytopathological Society Press, St. Paul, $\mathrm{MN}$ ) on 10 infected leaves per plot. Leaves of the same age were arbitrarily collected from each of three plots per treatment for analysis. The percentage of leaf area occupied by rust lesions was determined for each leaf, the individual leaf results for a plot were combined, and a mean infected area percentage was calculated for each treatment. Rust severity was determined on four dates during 2004: 20 April (12 days after the first fungicide treatment), 19 May (12 days after the third fungicide treatment), 7 June ( 6 days after the fifth fungicide treatment), and 19 June (18 days after the fifth fungicide treatment). Rust severity was determined only once during 2005 , on
1 July (16 days after the fourth and final fungicide treatment). Rust severity was determined twice during 2006: on 18 May (10 days after the first fungicide treatment) and 15 June (14 days after the fourth and final fungicide treatment).

Leaves emerge continuously at the shoot apex. A leaf is considered fully emerged once the collar at the junction of the leaf blade and sheath is visible. The youngest fully emerged leaf is referred to as the "top visible dewlap leaf" in sugarcane research literature. The second youngest fully emerged leaf was collected for image analysis on sampling dates during 2004. The fourth youngest fully emerged leaf was collected following the last fungicide treatment in 2005. The second youngest fully emerged leaf was collected on the two sampling dates during 2006.

Yield components determined for comparison included stalk population, stalk weight, stalk sucrose content (sucrose per ton of cane), cane tonnage produced per hectare, and total sucrose produced per hectare. Stalk population was estimated by counting all stalks in each plot during August. Stalk weight was estimated from the weight of a hand-cut 15 -stalk sample collected at the time of harvest during December each year. Each 15-stalk sample was cut continuously starting from an arbitrarily selected point within a plot. Brix (percent soluble solids) and Pol (percent in juice) measurements obtained from juice extracted from the 15-stalk sample were used to calculate commercially recoverable sucrose (CRS) per ton of cane (7). Cane tonnage yield was estimated from the weight of cane from each of the two plot rows combined. Cane was cut by a commercial chopper-type harvester and collected in a 5-ton, high-dump wagon equipped with weigh cells in the axel and tongue. Total sucrose yield was estimated by multiplying CRS by cane tonnage.

Rust severity and yield components were compared among treatments for each individual season and all three seasons combined using the PROC GLM procedure (SAS version 9.1.3; SAS Institute, Cary, NY), and treatment means were compared by Fisher's least significant difference analysis. Pearson correlation analysis was used to evaluate relationships between yield components and brown rust severity during individual seasons. Rust infection percentages were arc-sine transformed before analysis.

\section{RESULTS}

Application of a mixture of three fungicides on a biweekly basis reduced brown rust severity to a low level $(<5 \%)$ during the epidemic period without inducing any visible phytotoxicity symptoms. Brown rust severity late in the epidemic in nontreated plots was 22 and $38 \%$ for 2004 and 2005 , respectively, but only $10 \%$ for 2006 (Table 1). In all three years, rust severity was lower for treatments receiving full-season and late-season protection with fungicides compared with the treatment receiving early-epidemic protection only and the nontreated control. Rust severity in the treatment with only early-season protection was similar to severity when there was no fungicide applied.

Changes in rust severity over time were compared in the different treatments during the 2004 epidemic. Rust was observed during the 20 April assessment (Fig. 1). Disease severity in the nontreated control increased through May into early June, then did not increase further. Fungicide applications during April to provide early-

Table 1. Effect of brown rust on yield components of sugarcane cv. LCP 85-384 during three growing seasons ${ }^{\mathrm{x}}$

\begin{tabular}{|c|c|c|c|c|c|c|}
\hline $\begin{array}{l}\text { Fungicide } \\
\text { treatments }^{\mathrm{y}} \\
\end{array}$ & $\begin{array}{c}\text { Rust severity } \\
(\%)^{\mathbf{z}}\end{array}$ & $\begin{array}{c}\text { Stalks per hectare } \\
(\times 1,000)\end{array}$ & $\begin{array}{c}\text { Stalk weight } \\
(\mathrm{kg})\end{array}$ & $\begin{array}{c}\text { Sucrose per } \\
\text { ton of cane }(\mathbf{k g})\end{array}$ & $\begin{array}{c}\text { Tons of cane } \\
\text { per hectare }(t)\end{array}$ & $\begin{array}{c}\text { Sucrose } \\
\text { per hectare (t) }\end{array}$ \\
\hline \multicolumn{7}{|l|}{2004} \\
\hline None & $22.0 \mathrm{a}$ & 110.4 & $0.63 \mathrm{bc}$ & 109.5 & $74.8 \mathrm{~b}$ & $8.2 \mathrm{~b}$ \\
\hline Early & $24.4 \mathrm{a}$ & 115.6 & $0.56 \mathrm{c}$ & 108.0 & $78.2 \mathrm{ab}$ & $8.4 \mathrm{~b}$ \\
\hline Early-mid & $9.6 \mathrm{~b}$ & 108.7 & $0.72 \mathrm{ab}$ & 116.0 & $81.1 \mathrm{ab}$ & $9.4 \mathrm{ab}$ \\
\hline Full & $1.5 \mathrm{c}$ & 122.0 & $0.76 \mathrm{a}$ & 116.0 & $90.5 \mathrm{a}$ & $10.5 \mathrm{a}$ \\
\hline Mid-late & $1.2 \mathrm{c}$ & 112.4 & $0.68 \mathrm{ab}$ & 113.0 & $90.1 \mathrm{a}$ & $10.2 \mathrm{a}$ \\
\hline Late & $2.9 \mathrm{c}$ & 104.2 & $0.67 \mathrm{abc}$ & 113.5 & $69.9 \mathrm{~b}$ & $8.0 \mathrm{~b}$ \\
\hline \multicolumn{7}{|l|}{2005} \\
\hline None & $38.1 \mathrm{a}$ & 117.3 & 0.79 & 118.0 & $80.0 \mathrm{~b}$ & 9.5 \\
\hline Early & $45.1 \mathrm{a}$ & 126.0 & 0.88 & 115.5 & $83.3 \mathrm{~b}$ & 9.7 \\
\hline Full & $4.1 \mathrm{~b}$ & 119.3 & 0.82 & 110.8 & $94.7 \mathrm{a}$ & 10.5 \\
\hline Late & $4.0 \mathrm{~b}$ & 122.5 & 0.82 & 116.8 & $90.7 \mathrm{ab}$ & 10.6 \\
\hline \multicolumn{7}{|l|}{2006} \\
\hline None & $10.4 \mathrm{a}$ & 133.4 & 0.76 & 113.0 & 63.1 & 7.8 \\
\hline Early & $8.3 \mathrm{a}$ & 130.2 & 0.83 & 109.7 & 68.8 & 8.3 \\
\hline Full & $1.3 \mathrm{~b}$ & 127.1 & 0.78 & 108.3 & 73.7 & 8.8 \\
\hline Late & $1.4 \mathrm{~b}$ & 136.9 & 0.69 & 108.7 & 72.1 & 8.6 \\
\hline
\end{tabular}

${ }^{\mathrm{x}}$ Means within columns and years followed by the different letters were significantly different $(P=0.05)$ according to Fisher's least significant difference.

${ }^{y}$ A mixture of three fungicides was applied biweekly, with spraying beginning and ending on different dates to create different treatments in each of three years. Fungicides were applied to provide early, early-mid (2004 only), mid-late (2004 only), late, and full epidemic period protection against rust infection.

${ }^{\mathrm{z}}$ Image analysis was used to determine the mean percentage of leaf area occupied by brown rust lesions for 10 infected leaves per plot collected on 19 June 2004, 1 July 2005, and 1 July 2006. Rust infection percentages were arc-sine transformed for analysis; means presented were converted back to percentage values. 
epidemic protection delayed the increase of rust but then severity increased and was similar to the nontreated control by 18 June. Rust severity began to increase during June in the early- to mid-epidemic fungicide protection treatment but the final level of severity was less than $10 \%$. Rust development in the late-epidemic protection treatment was similar to the nontreated control at mid-epidemic during May but the fungicide applications in May and June resulted in rust severity levels in June of less than $5 \%$. Rust severity remained below $5 \%$ in all assessments in the full-season and mid-late-season fungicide protection treatments.

The analysis for all three seasons combined indicated a negative effect of brown rust on cane tonnage and the total amount of sucrose produced but no effect was detected on the individual plant yield components: stalk population, weight, sucrose content, and fiber content. The cane tonnage yield was $86.2 \mathrm{t} / \mathrm{ha}$ for the full-season fungicide protection treatment compared with $72.7 \mathrm{t} / \mathrm{ha}$ for the nontreated control (16\% lower, $P=0.02$ ), and the total sucrose yield was $9.9 \mathrm{t} / \mathrm{ha}$ compared with 8.5 t/ha (14\% lower, $P=0.02)$.

Differences were detected among treatments for some yield components in the 2004 and 2005 individual season experiments but not in the 2006 experiment (Table 1). During 2004, the epidemic began in
April and six treatments were compared. In contrast, the 2005 and 2006 epidemics did not begin until May, and the shorterduration epidemics allowed only four treatments to be compared.

Tons of cane and sucrose produced were lower in the nontreated control compared with the full-season and mid-late-season fungicide protection treatments in 2004, and stalk weight was lower in the nontreated control and early-epidemic protection treatment compared with the full-season treatment (Table 1). No differences were detected for the other yield components. Stalk weight and cane tonnage were both $17 \%$ lower and total sucrose yield was $22 \%$ lower in the nontreated control compared with the full treatment. Stalk weight and total sucrose yield were negatively correlated with brown rust severity $(r=-0.57$ and -0.50 , respectively; Table 2). In addition, sucrose per ton of cane was negatively correlated with brown rust severity $(r=-0.53)$.

The only significant difference detected during the 2005 season was for lower cane tonnage in the nontreated control and early-season protection treatment compared with the full treatment (Table 1). Cane tonnage was $16 \%$ lower in the nontreated control compared with the full treatment. Correlation analysis did not detect a relationship between any yield component and rust severity. No differ-

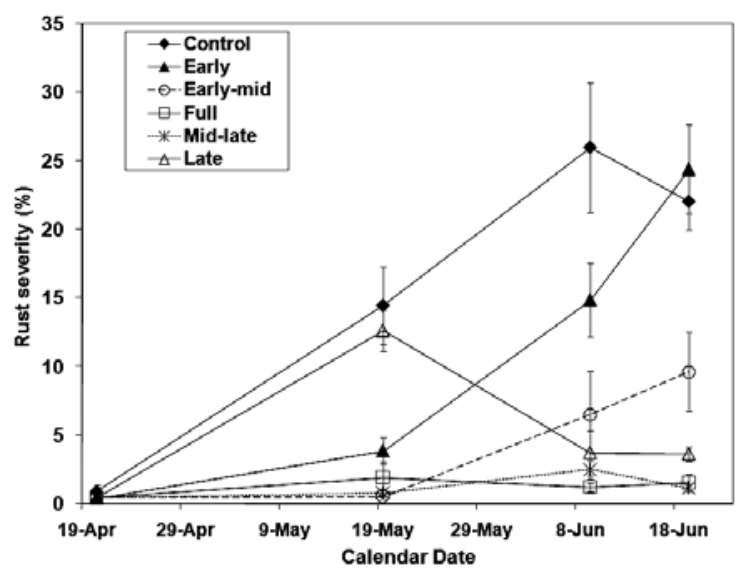

Fig. 1. Severity of brown rust in a 2004 field experiment in which disease was controlled with biweekly applications of a fungicide mixture that was applied at different times during the epidemic. Disease severity assessed as percent leaf area occupied by rust lesions was determined on four dates and compared for treatments, including a nontreated control (Control) and fungicide applications made during April only (Early); April and May (Early-mid); April, May, and June (Full); May and June (Mid-late), and June only (Late). ences were detected among treatments and no correlation was found between yield components and rust severity for the 2006 season, when severity only reached $10 \%$.

\section{DISCUSSION}

In this study, the application of a fungicide mixture at 2 -week intervals through the duration of an epidemic reduced brown rust severity and allowed the effect of disease on sugarcane yield to be estimated in cv. LCP 85-384. Cane tonnage and total sucrose yields were 16 and $14 \%$ lower, respectively, over three seasons in plots with naturally occurring rust epidemics compared with those receiving fullepidemic fungicide protection. The greatest yield reductions demonstrated were $17 \%$ for cane tonnage and $22 \%$ for total sucrose yield in the longest-duration epidemic during 2004. Susceptible sugarcane cultivars can vary in the amount of yield loss caused by brown rust $(2,6,11,13$, 16,17). Reported losses have ranged from 13 to $51 \%$. The full range of possible losses due to brown rust in sugarcane cultivars in Louisiana remains to be determined.

Sugarcane farmers monitor yield as cane tonnage and, ultimately, are paid for the total amount of sucrose produced. The individual stalk yield componentspopulation, weight, and sucrose contenttogether determine the aggregate components of total cane tonnage and sucrose yield. The individual stalk yield components were evaluated to attempt to determine how brown rust causes losses in the aggregate yield components. The only significant effect detected was a reduction in stalk weight during the longest epidemic in 2004, and stalk weight was negatively correlated with rust severity during this season. Plant height differences were visually evident in plots continuously treated with fungicides compared with nontreated plots in the experiments but stalk height data was not collected. The differences among treatments for sucrose per ton of cane were small and not significant in the 2004 epidemic. However, the negative correlation detected between stalk sucrose content and rust severity suggests that a rust effect on this individual stalk yield component could be contributing to reductions demonstrated for the aggregate yield components. The results suggest that reductions in total cane tonnage and sucrose

Table 2. Correlation coefficients from Pearson correlation analysis to evaluate relationships between brown rust severity and yield components during 2004 experiment

\begin{tabular}{|c|c|c|c|c|c|c|}
\hline & Rust severity & Stalk population & Stalk weight & $\begin{array}{l}\text { Sucrose per } \\
\text { ton of cane }\end{array}$ & $\begin{array}{c}\text { Cane tonnage } \\
\text { yield }\end{array}$ & Total sucrose yield \\
\hline Rust severity & 1.00 & $-0.03(P=0.89)$ & $-0.57(P=0.01)$ & $-0.53(P=0.02)$ & $-0.38(P=0.12)$ & $-0.50(P=0.03)$ \\
\hline Stalk population & $-0.03(P=0.89)$ & 1.00 & $-0.06(P=0.79)$ & $0.12(P=0.58)$ & $0.44(P=0.03)$ & $0.45(P=0.03)$ \\
\hline Stalk weight & $-0.57(P=0.01)$ & $-0.06(P=0.79)$ & 1.00 & $0.22(P=0.30)$ & $0.10(P=0.65)$ & $0.17(P=0.44)$ \\
\hline Sucrose per ton of cane & $-0.53(P=0.02)$ & $0.12(P=0.58)$ & $0.22(P=0.30)$ & 1.00 & $0.11(P=0.61)$ & $0.40(P=0.05)$ \\
\hline Cane tonnage yield & $-0.38(P=0.12)$ & $0.44(P=0.03)$ & $0.10(P=0.65)$ & $0.11(P=0.61)$ & 1.00 & $0.95(P<0.0001)$ \\
\hline Total sucrose yield & $-0.50(P=0.03)$ & $0.45(P=0.03)$ & $0.17(P=0.44)$ & $0.40(P=0.05)$ & $0.95(P<0.0001)$ & 1.00 \\
\hline
\end{tabular}


yields result from a combination of reductions in multiple individual stalk yield components. Previous research found that brown rust can adversely affect stalk population (16) or stalk size $(13,16,17)$, whereas sucrose content is not affected $(13,16,17)$. In a pot study, reductions in total plant weight were attributed to reduced stalk height (2). A consideration of all the evidence related to brown rust effects on individual stalk yield components suggests that reduced shoot growth resulting in lower stalk weight is the greatest but not only adverse impact of the disease on sugarcane growth and yield.

Applying fungicides and controlling brown rust at different times allowed a comparison of the impact of the disease on yield early versus late during the epidemic period. The most conclusive results were obtained in the longer epidemic during 2004, with evidence provided by a comparison of six treatments for three yield components. The results suggest that the impact of brown rust on yield is greatest during the middle and late stages of the epidemic. It was more difficult to detect differences among treatments and any correlation between yield components and disease severity when comparing only four treatments for the 2005 and 2006 epidemics. The results for cane tonnage from 2005 support the conclusion that rust causes more damage to the crop during the middle and late epidemic period. The rankings of the treatments were similar in the 2006 experiment but the results were not significant, probably due to the lower rust severity.

A transition from tillering to stem elongation and stalk formation occurs in a sugarcane crop during the course of a typical brown rust epidemic. The elongation of stems to produce stalks increases rapidly with the onset of higher summer temperatures; therefore, the observed adverse effect of rust on stalk weight would be likely to occur during May and June.

The magnitude of the yield reductions caused by brown rust in this study would have a major economic impact on sugarcane farmers if the losses encompassed the entire industry. LCP $85-384$ was rated as resistant to brown rust when it was released in 1993 (8). Widespread, severe brown rust symptoms were first observed in 2000 but this highly successful cultivar was cultivated on $91 \%$ of the production area in 2004 (4). It still occupied more than $46 \%$ of the area during 2007 (5), demonstrating the difficulty in rapidly changing cultivars in sugarcane.

Management of brown rust with fungicides is not an established practice in sugarcane production. The effectiveness of a fungicide mixture in reducing brown rust severity and the resulting higher yield demonstrated in this study suggest that an on-farm fungicide program for disease management could be effective. The relative efficacy of strobilurin and triazole fungicides or mixtures of the two fungicide types for brown rust control needs to be determined. The relationship between cost and efficacy is always a concern with chemical control programs. The results from this study found that fungicide applications targeting only the beginning of the epidemic did not prevent yield loss, whereas protection during the middle and late portions of an epidemic maintained yield potential. Additional research is needed but the results suggest it might not be necessary to begin fungicide sprays at the very beginning of the epidemic to prevent significant yield loss. This might reduce the cost of a fungicide control program; however, more than one application of an effective fungicide treatment may be necessary to provide enough protection to prevent yield loss.

There will be an ongoing effort to breed and select brown-rust-resistant cultivars. However, the disease is likely to continue to be a cyclical problem, and an alternative management practice using fungicides could help to prevent or minimize the losses caused by brown rust when cultivar susceptibility becomes a problem.

\section{ACKNOWLEDGMENTS}

We thank C. Savario, Research Associate, Louisiana State University Agricultural Center, for expert technical assistance; and W. Jackson and $\mathrm{H}$. Waguespack, Agronomists, the American Sugar Cane League, for assistance in harvesting the experiments.

\section{LITERATURE CITED}

1. Comstock, J. C., and Ferreira, S. A. 1986. Sugarcane rust: Factors affecting infection and symptom development. Proc. Int. Soc. Sugar
Cane Technol. 19:402-410.

2. Comstock, J. C., Shine, J. M., and Raid, R. N. 1992. Effect of rust on sugarcane growth and biomass. Plant Dis. 76:175-177.

3. Dean, J. L., and Purdy, L. H. 1984. Races of sugarcane rust fungus, Puccinia melanocephala, found in Florida. Sugar Cane 1984(1):15-16.

4. Legendre, B. L., and Gravois, K. A. 2005. The 2004 Louisiana sugarcane variety survey. Sugar Bull. 83(9):15-21.

5. Legendre, B. L., and Gravois, K. A. 2008. The 2007 Louisiana sugarcane variety survey. Sugar Bull. 86(8):18-22.

6. McFarlane, K., McFarlane, S. A., Moodley, D., and Rutherford, R. S. 2006. Fungicide trials to determine the effect of brown rust on the yield of sugarcane variety N29. Proc. S. Afr. Sugar Technol. Assoc. 80:297-300.

7. Meade, G. P., and Chen, J. C. P. 1977. Cane Sugar Handbook. Wiley and Sons, New York.

8. Milligan, S. B., Martin, F. A., Bischoff, K. P., Quebedeaux, J. P., Dufrene, E. O., Quebedeaux, K. L., Hoy, J. W., Reagan, T. E., Legendre, B. L., and Miller, J. D. 1994. Registration of 'LCP 85-384' sugarcane. Crop Sci. 34:819-820.

9. Purdy, L. H., Liu, L.-J., and Dean, J. L. 1983. Sugarcane rust, a newly important disease. Plant Dis. 67:1292-1296.

10. Raid, R. N. 1989. Physiological specialization in sugarcane rust (Puccinia melanocephala) in Florida. Plant Dis. 73:183.

11. Raid, R. N., Anderson, D. L., and Coale, F. J. 1991. Yield loss incited by Puccinia melanocephala on a highly susceptible sugarcane cultivar in Florida. (Abstr.) Phytopathology 81:699.

12. Raid, R. N., and Comstock, J. C. 2000. Common rust. Pages 85-89 in: A Guide to Sugarcane Diseases. P. Rott, R. A. Bailey, J. C. Comstock, B. J. Croft, and A. S. Saumtally, eds. CIRAD and ISSCT.

13. Scarlett, B. 1980. Thoughts on yield loss assessment of sugarcane affected by the rust disease. Jamaican Assoc. Sugar Technol. J. 41:254-257.

14. Shine, J. M., Comstock, J. C., and Dean, J. L. 2005. Comparison of five isolates of sugarcane rust and differential reaction on six sugarcane clones. Sugar Cane Int. 23(5):24-29.

15. Srinivasan, K. V., and Muthaiyan, M. C. 1965. A note on physiological races of Puccinia erianthi Padw. \& Khan affecting sugarcane varieties. Proc. Int. Soc. Sugar Cane Technol. 12:1126-1128.

16. Taylor, P. W. J., Croft, B. J., and Ryan, C. C. 1986. Studies into the effect of sugarcane rust (Puccinia melanocephala) on yield. Proc. Int. Soc. Sugar Cane Technol. 19:411-419.

17. Zvoutete, P. 2006. Fungicide sprays to control brown rust gave variable cane and sugar yield responses in the South-east Lowveld of Zimbabwe. Proc. S. Afr. Sugar Technol. Assoc. 80:301-306. 